\title{
TINGGALAN BATU LUMPANG DI DESA RUKO, KECAMATAN \\ TOBELO: Tinjauan atas Konteks Sejarah dan Sosial Budaya Kerajaan-Kerajaan Lokal di Halmahera Utara
}

\section{Remains of Batu Lumpang in Ruko Village, Tobelo District: Overview on History and Socio-Cultural Context Local Empire at North Halmahera}

\author{
Karyamantha Surbakti \\ Balai Arkeologi Ambon-Indonesia \\ J1. Namalatu-Latuhalat, Ambon 97118 \\ manthatorong@gmail.com
}

Naskah diterima: 27-01-2015; direvisi: 20-04-2015; disetujui: 25-05-2015

\begin{abstract}
Batu Lumpang in the archaeological perspecitve is known as remains with the characteristic as a tool for mashing food. This stone has a container shape that made of stone vessels were notched in the middle. The purpose of this study is to initiate the prelimenary study of the batu lumpang in the Ruko village, the District Tobelo, North Halmahera and will be use as a data that assist the interpreationt and explaination on the history of North Halmahera. The research method adopted in this study is observation and interviews. Qualitative analysis and ethnoarchaeology analysis has been adopted to see the depth of the data to be interpreted. Results of the study shows that the factors of hegemony of the Ternate empire who conquered Moro and an abundance of food sources in Moro, as well as the strong indication of batu lumpang as the main supporting objects for the economic activity at that time.
\end{abstract}

Keywords: stone mortar, hegemonic power, elements of a foreign nation, the historical context, and socio-cultural

\begin{abstract}
Abstrak
Batu lumpang dalam khasanah arkeologi dikenal sebagai tinggalan dengan ciri yang mengarah sebagai alat menumbuk makanan. Batu ini merupakan wadah yang berbentuk bejana terbuat dari batu yang berlekuk di tengahnya. Tujuan dari penelitian ini sebagai studi awal dalam melihat tinggalan batu lumpang yang ada di Desa Ruko Kec. Tobelo Kab. Halmahera Utara sebagai data yang membantu menginterpretasi dan menjelaskan sebuah peristiwa sejarah yang panjang di Halmahera Utara. Metode penelitian menggunakan observasi langsung dan wawancara. Analisis kualitatif dan analisis etnoarkeologi diperlukan untuk melihat kedalaman data yang hendak diinterpretasikan. Hasil dari penelitian adalah faktor hegemoni kekuasaan dari kerajaan Ternate yang menaklukkan kerajaan Moro dan berlimpahnya sumber bahan pangan di Moro menjadikan indikasi kuat batu lumpang sebagai penyokong aktivitas ekonomi pada kala itu.
\end{abstract}

Kata kunci: batu lumpang, hegemoni kekuasaan, anasir bangsa asing, konteks sejarah, dan sosial budaya

\section{PENDAHULUAN}

Penelitian ini dilakukan di daerah Halmahera Utara yang memiliki cukup potensi historiografi yang kompleks. Pulau Halmahera dan pulau-pulau sekitarnya termasuk Bacan terletak kira-kira antara $127^{\circ}$ dan $129^{\circ} 40^{\prime}$ Bujur Timur (BT), $2^{\circ} 59^{\prime}$ Lintang Utara (LU) dan $1^{\circ} 53^{\prime}$ ' Lintang Selatan (LS). Pulau Halmahera pulau yang terbesar dari rangkaian pulau yang ada dan sekitar $170 \mathrm{~km}$ dari utara ke selatan, dan $80 \mathrm{~km}$ dari timur ke barat, enam pulau di 
sekitar Halmahera, yang terbesar adalah Pulau Morotai yang terletak di sebelah timur laut, sedangkan di barat laut terdapat Kepulauan Bacan, Obi, dan Sula. Luas Kepulauan Halmahera diperkirakan 20.000 $\mathrm{km} 2$. Bagian utara terdapat banyak gunung berapi. Gunung tertinggi adalah Gunung Gamkonora dengan puncak tertinggi 1569 $\mathrm{m}$. Gunung ini membentuk suatu barisan, mulai dari distrik Tobelo ke selatan hingga pulau-pulau yang sejajar antara lain Pulaupulau Hiri, Ternate, Maitara, Tidore, Moti, dan Makian.

Wilayah Halmahera sejak bagian pertama abad ke-14, telah menjadi ajang perebutan hegemoni politik kekuasaan. Hal tersebut mendorong terbentuknya aliansi kekuasaan berupa konfederasi politik kerajaan lokal di Halmahera Utara seperti Loloda, Moro maupun masuknya pengaruh dari luar seperti kerajaan Bacan, Jailolo, Ternate dan Tidore. Empat kerajaan dari luar itu yang biasa juga disebut dengan Maloku Kie Raha silih berganti mempengaruhi berbagai ranah kehidupan masyarakat Halmahera Utara bukan saja berkaitan dengan kekuasaan tetapi berkaitan juga dengan pembentukan struktur ekonomi dan sosial budaya masyarakat Halmahera Utara (Naping, $2013: 6$ ).

Kekuatan politik dan kekuasaan tradisional diberbagai wilayah diHalmahera Utara sesungguhnya telah terbangun jauh sebelum masuknya pengaruh Ternate dan Tidore serta bangsa barat. Ketika itu kerajaan Loloda dan Moro telah menjalin hubungan dan komunikasi dengan berbagai wilayah di berbagai tempat, termasuk pusat kekuasaan di Maluku saat itu yakni Ternate. Kerajaan Loloda dianggap sebagai salah satu kerajaan tertua di Maluku, yang terletak di ujung utara pulau Halmahera. Kapan dan siapa pendiri kerajaan ini belum diketahui dengan jelas. Penguasa awal masih didasarkan pada mitos telur naga, yang menyebutkan bahwa raja Loloda berasal dari keturunan telur naga yang suci. Dalam sejarah penguasa-penguasa Maluku,
Loloda selalu menempati tempat khusus dalam upacara para raja, dan juga berhak menyandang gelar Kolano. Dua dari empat kekuatan politik tersebut kemudian tampil lebih unggul dan mampu mengendalikan kekuatan politik di Halmahera Utara yaitu Ternate dan Tidore. Meskipun kedua kerajaan itu berada pada sebuah pulau yang kecil, tetapi mampu menguasai kerajaan di pulau yang besar seperti Jailolo di Halmahera, juga kerajaan Bacan. Ternate dan Tidore merupakan kekuatan politik di Maluku Utara yang sering berseteru untuk memperebutkan keunggulan politiknya. Hal itu membuat keduanya harus selalu berupaya memperkuat diri, antara lain dengan memanfaatkan kelompok (masyarakat) lain sebagai penyangga kekuatannya. Dalam konteks inilah, masyarakat Halmahera Utara selalu dalam bayang-bayang politik kedua kerajaan yang berpengaruh itu. Berpihak pada salah satu kerajaan berarti menjadi musuh pada kerajaan yang lain. Jika tidak berpihak, maka akan menjadi incaran penguasaan bagi keduanya.

Desa Ruko terletak di Kecamatan Tobelo, Kabupaten Halmahera Utara. Tim Balai Arkeologi Ambon pada pertengahan Februari 2014 melakukan penelitian dan menemukan tinggalan batu lumpang. Menurut informasi setempat bahwa lokasi ditemukannya batu lumpang merupakan wilayah cakupan dari kekuasaan lokal yaitu kerajaan Moro yang takluk terhadap kerajaan Ternate. Desa ini kemudian menjadi pusat pengolahan makanan dan akan dikirim ke Ternate. Berdasarkan latar belakang tersebut, maka pokok permasalahannya disusun sebagai berikut.

1. Bagaimana gambaran keterkaitan konteks sejarah antara batu lumpang di Desa Ruko terhadap geliat kerajaan lokal di Halmahera Utara kala itu?

2. Faktor apa saja yang menjadikan batu lumpang memiliki indikasi kuat sebagai penyokong aktivitas kehidupan kala itu? 
Tinjauan Pustaka sangat dibutuhkan untuk memberikan gambaran umum yang sangat mendasar mengenai daerah Halmahera Utara. Tulisan ini menggunakan informasi dari buku M. Adnan Amal tahun 2010 yang berjudul Kepulauan RempahRempah Perjalanan Sejarah Maluku Utara 1250-1950 serta buku Tobelo Tempo Doeloe tahun 2013. Penulis juga menggunakan buku Portugis dan Spanyol di Maluku tahun 2010 karya Adnan Amal sebagai referensi utama. Buku Halmahera Utara Sejarah Perkembangan Peradaban di Bumi Hibualamo tahun 2013 merupakan buku selanjutnya buah karya Hamka Naping. Buku ini juga memberikan penjelasan mengenai sejarah panjang yang terjadi seputar perebutan kekuasaan antar kerajaan lokal yang ada di Halmahera serta masuknya penjajahan bangsa asing yang mendarat di Maluku Utara.

\section{Buku Sejarah Nasional Indonesia} Jilid I tahun 1996 merupakan buku pegangan pokok dalam memahami tinggalan dan artefak yang ada di Indonesia. Penjelasan R.P. Soejono mengenai pembabakan sejarah dan penggambaran kehidupan prasejarah di Indonesia sangat diperlukan untuk memahami konteks batu lumpang sebagai tinggalan yang digunakan sebagai media/alat yang berkaitan dengan pengolahan bahan pangan ataupun makanan. Pustaka lainnya yang penulis gunakan untuk referensi adalah buku dari karya Leonard Andaya berjudul "Dunia Maluku Indonesia Timur Pada Zaman Modern Awal" yang dikeluarkan oleh Penerbit Ombak pada tahun 2015, berisi informasi yang menyebutkan secara eksplisit bahwasanya daratan Maluku kala itu memiliki banyak pergolakan antara kerajaan lokal dan bangsa Eropa yang memiliki kepentingan untuk pengumpulan rempah-rempah. Buku ini juga menjelaskan geliat beberapa kerajaan lokal beserta tokoh sentral dalam sistem kesultanan yang ada demi mempertahankan eksistensinya melakukan negosiasi dan konfrontasi dengan bangsa penjajah.
Referensi terakhir yang penulis gunakan untuk bahan bacaan dalam tulisan ini adalah Laporan Penelitian Balai Arkeologi Ambon tahun 2014 dengan judul "Jejak Peradaban Islam dan Pengaruh Kesultanan Ternate di Pulau Halmahera". Penelitian ini dilakukan untuk menelusuri sejauh mana pengaruh dan perkembangan Islam yang berasal dari Kesultanan Ternate. Dalam beberapa literatur, selain wilayah Kepulauan Maluku bagian Selatan, Kesultanan Ternate juga melakukan ekspansi ke wilayah-wilayah di bagian Maluku Utara, terutama daratan Pulau Halmahera. Penelitian ini mencoba untuk menemukan bukti-bukti arkeologis dan informasi tutur mengenai sejarah pengaruh Islam di wilayah kekuasaan Ternate di Maluku Utara.

Penelitian ini memiliki dua tujuan, yaitu tujuan umum dan tujuan khusus. Kedua tujuan itu dapat diuraikan sebagai berikut.

Tujuan umum arkeologi sebagai sebuah disiplin ilmu tidak terlepas dari pemahaman tentang kebudayaan masa lalu yang didasarkan pada tiga tujuan yaitu rekonstruksi sejarah budaya, rekonstruksi cara-cara hidup, dan penggambaran proses budaya (Binford, 1972 : 104). Merujuk pada tiga tujuan tersebut maka penelitian ini dititikberatkan pada tujuan arkeologi yang ketiga.

Secara umum, penelitian ini bertujuan untuk memahami pengunaan tinggalan batu lumpang dan konteks sejarah kala itu yang berkaitan dengan kerajaan lokal Moro terhadap kerajaan Ternate.

Tujuan khusus dari penelitian ini adalah; (a) melihat gambaran keterkaitan konteks sejarah antara batu lumpang di Desa Ruko terhadap geliat kerajaan lokal di Halmahera Utara kala itu (b) mengetahui faktor apa saja yang menjadikan batu lumpang memiliki indikasi kuat sebagai penyokong aktivitas kehidupan kala itu.

Manfaat dari penelitian ini antara lain; (a) secara teoretis, hasil penelitian ini dapat membantu sumbang pemikiran ilmiah bagi ilmu pengetahuan bidang arkeologi, 
khususnya tentang tinggalan batu lumpang yang notabene merupakan sebuah bukti fisik dari sejarah pada masa lalu yang bertalian erat dengan sumber makanan dan pengolahannya dan kemudian (b) secara praktis, bagi pemerintah daerah, dapat menjadi masukan dalam mengambil kebijakan yang berkaitan dengan perlindungan kepurbakalaan di Maluku Utara.

\section{METODE}

Penelitian budaya yang menggunakan model kualitatifbiasanya mengejar data verbal yang dianggap lebih mewakili fenomena dalam suatu budaya tertentu. Alasan utama pemakaian penelitian kualitatif budaya, antara lain data yang diperoleh dari lapangan biasanya tidak berstruktur dan relatif banyak, sehingga memungkinkan peneliti untuk lebih menata, mengkritisi dan mengklasifikasikan yang lebih menarik melalui penelitian kualitatif (Endraswara, 2006: 82).

Pengumpulan data dalam penelitian ini menggunakan cara berupa survei permukaan dan pengamatan langsung di lapangan (observasi). Untuk informasi tambahan digunakan wawancara tidak berstruktur (pertanyaan terbuka) guna mendapatkan keleluasaan dalam mengarahkan pertanyaan kepada informan dan melacak informan lainnya berdasarkan informasi dari informan yang sudah ada (snow ball). Setelah tahap pengumpulan data yang berupa survey, observasi dan wawancara, maka data mentah lapangan ini perlu diolah kemudian melalui pendekatan analisis kualitatif, analisis kontekstual, dan analisis etnoarkeologi.

Pendekatan yang pertama adalah analisis kualitatif yaitu pengolahan data yang bersifat konsep, asumsi, dan pengertian abstrak yang diuraikan dari kualitas data. Pendekatan kualitatif juga menganalisis artefak berupa batu lumpang yang terkait dengan fungsinya sebagai alat penumbuk makanan berupa padi dan umbi-umbian. Kemudian data-data tersebut disintesakan dan diinterpretasikan.
Pendekatan berikutnya adalah analisis kontekstual yaitu mengadakan analisis dengan melihat hubungan atau keterkaitan antara data yang satu dengan yang lainnya dalam tingkatan tertentu. Fokus analisis ini terutama adalah hubungan suatu lokasi tempat ditemukannya batu lumpang dengan daerah yang disinyalir sebagai daerah distribusi.

Pendekatan yang terakhir adalah analisis etnoarkeologi. Prinsip yang dipakai untuk mengetahui sejarah masa kini dan masa lalu adalah analogi etnografi. Terdapat premis yang menyatakan bahwa jika dua kelompok gejala memiliki kesamaan dalam hal tertentu (misalkan bentuk dan fungsi) maka keduanya mungkin akan mempunyai kesamaan pula dalam beberapa hal lainnya (misalnya cara pembuatan dan cara memakai) (Simanjuntak, et al, 1999: 188189). Dalam hal ini arkeologi digunakan untuk mengidentifikasi dan menetapkan hubungan antara data arkeologi berdasarkan perbandingan dengan gejala serupa yang masih dapat ditemukan dalam masyarakat yang masih hidup.

\section{HASIL DAN PEMBAHASAN}

Batu Lumpang merupakan sebuah perkakas yang dapat digolongkan ke dalam alat yang digunakan pada masa bercocok tanam. Menilik kondisi dari beberapa lokasi penemuan tinggalan ini, ada kecenderungan manusia pada masa lalu untuk mendiami tempat terbuka yang dekat dengan air seperti pinggir sungai, tepian danau dan daerah pantai. Ada kalanya yang didiami adalah tempat yang agak tinggi dan bukitbukit kecil yang dikelilingi sungai atau jurang serta dipagari oleh hutan. Tujuannya adalah melindungi diri dari serangan musuh dan hewan buas. Terkadang untuk tujuan tersebut dibuat tanggul-tanggul dan paritparit pertahanan di sekeliling tempat tinggal (Soejono, 1996: 195).

Permukiman menetap muncul ketika masa tradisi bercocok tanam berkembang. Masyarakat pada masa itu untuk memenuhi 
kebutuhannya, sudah tidak lagi hidup secara mengembara, tetapi bermukim menetap di suatu tempat secara mengelompok. Mereka memilih lokasi sesuai dengan lingkungan alam yang memenuhi kebutuhannya, misalnya di gua-gua yang dekat dengan sumber makanan atau tempat-tempat terbuka di pinggir sungai. Kehidupan manusia tidak terlepas dari lingkungan sekitar. Manusia akan berusaha memilih lingkungan yang sesuai untuk aktivitasnya dengan memanfaatkan sumber daya alam secara optimal (Herkovits, 1952: 3-8).

Lokasi penelitian berada di desa Ruko yang memiliki derajat geografis LU 0146'16.0" dan BT 12757'32.2" serta memiliki ketinggian $\pm 9 \mathrm{~m}$ dpl. Desa ini berada di daerah administratif Kecamatan Tobelo. Berada tidak terlalu jauh dari jalan lintas kabupaten, lokasi ditemukannya batu lumpang cukup mudah dicapai. Untuk mencapai lokasi situs tersebut, kita melewati perkebunan penduduk yang banyak ditanami pisang. Vegetasi sekitar lokasi ditemukannya batu lumpang juga cukup variatif dengan banyak tumbuhan perdu dan ilalang. Sepanjang jalan menuju lokasi sedikit

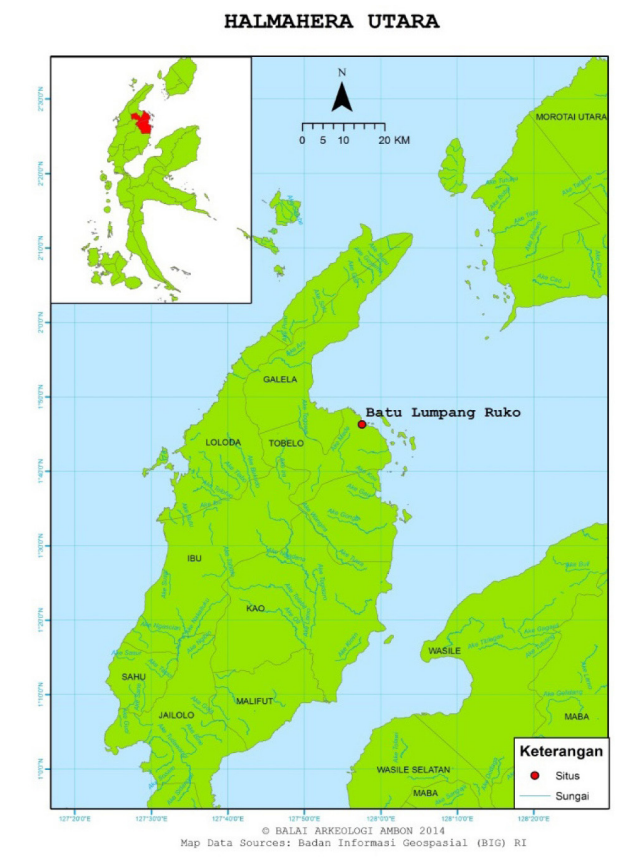

Gambar 1. Lokasi penelitian

(Sumber: Balai Arkeologi Ambon ArcGIS 10.1) menanjak dengan mengikuti alur sungai.

Aliran sungai cukup deras yang langsung mengalir ke hilir di Tanjung Ruko. Lokalitas di situs yang terdapat tinggalan batu lumpang tersebut memiliki ciri situs yang agak tertutup dan tidak banyak diketahui orang banyak. Batu lumpang tergeletak di perkebunan masyarakat setempat.

Batu lumpang terletak di permukaan tanah dan memiliki orientasi sebelah selatan Sungai Mede atau sebelah barat dari teluk Ruko. Batu ini memiliki diameter atas 48 $\mathrm{cm}$, diameter bawah $15 \mathrm{~cm}$ dan tinggi dari permukaan tanah $27 \mathrm{~cm}$ (Tim Penelitian, 2014: 43). Temuan batu lumpang (lesung) ini dianggap cukup penting meskipun di lapangan hanya ditemukan satu buah. Temuan batu lumpang memberikan ketegasan atas peran situs dalam perkembangan permukiman masyarakat pendukungnya pada masa lampau. Selain itu dapat memberikan gambaran tentang aktifitas penduduk, soal mengolah lahan sumberdaya, tradisi bercocok tanam dan sebagainya. Di situs Ruko, dari singkapan tanah di daerah bantaran sungai juga ditemukan indikasi susunan batu yang digunakan sebagai perbentengan tradisional (Tim Penelitian, 2014: 44).

Beberapa sumber menyatakan bahwa Situs Ruko merupakan salah satu situs kampung tua, sebuah tempat bermukim masyarakat Ruko pada masa lampau. Tradisi tutur menyebutkan, Ruko merupakan salah satu benteng pertahanan tradisional masyarakat pada masa lampau sebelum dikuasai Portugis. Sumber lain menyebutkan, wilayah ini pada masa pendudukan Portugis pernah dijadikan sebagai lokasi pertahanan Bangsa Portugis. Portugis sempat membangun benteng di lokasi tersebut, namun belum selesai pengerjaannya sudah dihancurkan oleh Belanda. Pada masa itu sekitar tahun 1557, Ruko dikuasai oleh Portugis, dijadikan sebagai pusat pemukiman, sebelum kemudian pindah di wilayah Mamuya, sebelah selatan Ruko sekarang. Pada saat 
survei, ditemukan struktur batu yang diduga sebagai susunan batu bekas perbentengan, yang kemungkinan menunjukkan bekas struktur benteng tradisional masyarakat Ruko sebelum dikuasai Portugis.

Wawancara yang dilakukan terhadap penduduk setempat di lokasi dimana terdapat batu lumpang tersebut, diperoleh informasi bahwa batu tersebut sudah lama ada dan digunakan oleh leluhur mereka. Informan di lapangan juga memberikan penjelasan mengenai batu lumpang yang merupakan sebuah teknologi pengupas kulit padi atau alat/ perkakas penumbuk umbi pada masa itu. Penulis memiliki asumsi dasar bahwa setiap tinggalan yang memiliki ciri/ karakter dari masa bercocok tanam seperti batu lumpang dimaksud, dan masih digunakan sampai masa kerajaan Moro, maka besar kemungkinan hal tersebut adalah sebuah benda yang masih dipakai terus hingga beberapa periode sesudahnya.

Tradisi oral setempat menuturkan bahwa kerajaan Moro terletak di pantai timur Halmahera Utara, yang terbentang dari Tanjung Biso di utara sampai Tobelo. Wilayah Moro yang berada di daratan disebut Moro-tia, sedangkan wilayahnya yang di seberang lautan disebut dengan Moro-tai (Moro lautan). Ibukota kerajaan terletak di Mamuya, yang sekarang termasuk kecamatan Galela. Tidak diketahui secara pasti awal mula kerajaan ini, namun hasil kajian dari sejarawan A.B Lapian menyebutkan bahwa Kerajaan Moro sama tuanya dengan Kerajaan Loloda serta sumber-sumber Portugis dan Spanyol menyebut Pulau Halmahera juga sebagai Jailolo atau "Batuchina de Moro" (Naping, 2013:80).

Kota penting Kerajaan Moro adalah Mamuya. Selain itu, kota penting lainnya adalah Sugala, Pune (Galela), Tolo, Cawa, Samafo (Tobelo), Sakita, Mira, Cio dan Rao. Penduduknya menganut agama Islam, sebagian agama Kristen dan kepercayaan lama (lokal). Secara geografis kerajaan ini terdiri atas etnis Galela dan Tobelo. Mereka berasal dari kelompok hoana Morodina, Morodai, Lina, Gura, Mumulati dan Huboto (Amal, 2010a: 213-214). Daerah kerajaan ini merupakan penghasil beras terbesar di Maluku. Faktor tersebut menjadikan Moro sebagai gudang pangan, khususnya beras dan sagu serta ikan dan daging bagi kota Ternate. Perkembangan kerajaan ini terhambat oleh bayang-bayang kekuasaan Kerajaan Jailolo di daratan Pulau Halmahera dan Kerajaan Ternate di seberang lautan.

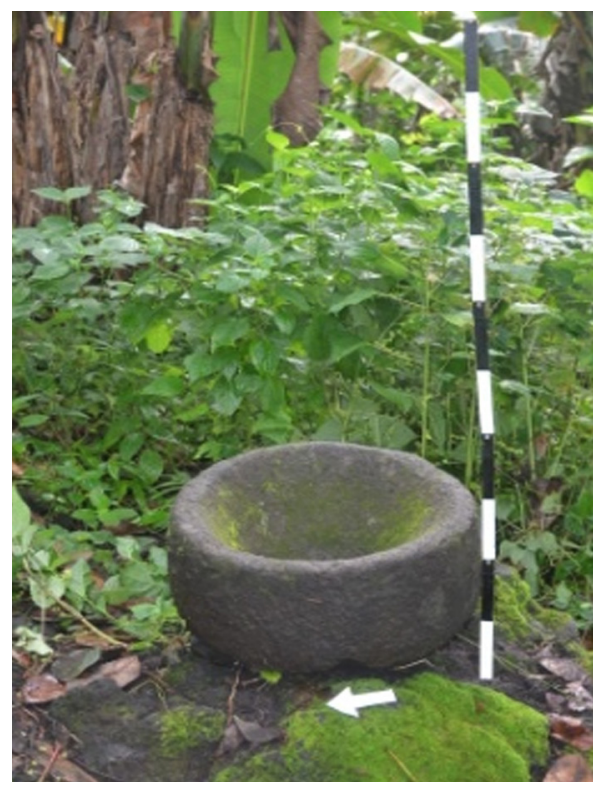

Gambar 2. Batu Lumpang

(Sumber : Dok. Balar Ambon 2014)

Potensi daerahnya yang sebagai
lumbung pangan menyebabkan kedua kerajaan tersebut bergiat untuk menguasainya. Daya tarik lainnya adalah sumber daya manusia Hibualamo yang mendiami daerah pesisir dan lautan (kepulauan) sebagai tenaga-tenaga terampil dalam pembuatan perahu (juanga) yang dapat mendukung kebijakan kerajaankerajaan itu di bidang kelautan. Ketika di tengah kondisi terancamnya keamanan dan kenyamanan hidup masyarakat itu, datanglah bangsa Eropa, khususnya bangsa Portugis di Moro. Situasi itu dimanfaatkan Portugis untuk menarik hati raja Moro, dengan menawarkan kekuatan untuk melindunginya dari ancaman kerajaan Jailolo dan kerajaan Ternate. 
Penjelasan di atas dapat diinterpretasikan bahwa potensi dari daerah Kerajaan Moro membuat sebuah tatanan sosial budaya yang berbeda. Pertama; daerah itu harus membuat ketahanan pangan bagi masyarakat mereka sendiri, dan kedua; mereka harus menjaga ketersediaan pangan yang akan dikirim ke Ternate sebagai imbas dari daerah taklukan.

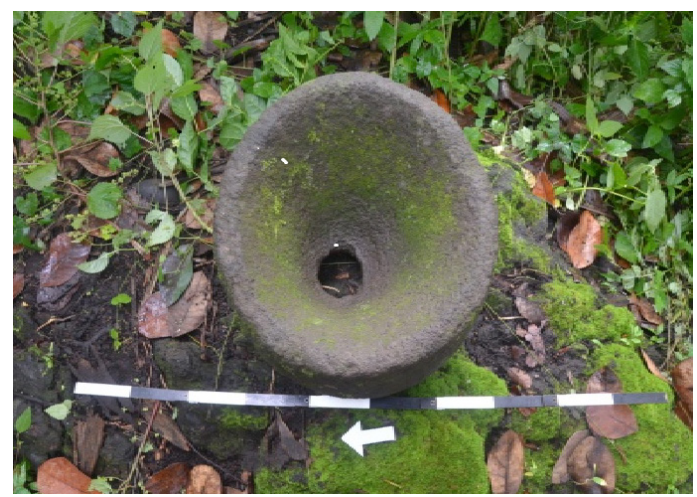

Gambar 3. Batu lumpang tampak atas (Sumber: Dok. Balar Ambon 2014)

Hal tersebut mungkin sudah sangat lama berlangsung, ketika Tim penelitian Balai Arkeologi Ambon mewawancarai seorang narasumber yang mengatakan dulu sekitar medio 1970-an, ratusan batu lumpang terdapat di desa Ruko. Pada saat sekarang sudah banyak yang dicuri karena untuk kebutuhan campuran kerakal bagi pembuatan rumah dan aspal jalan raya.

Pada umumnya dapat dikatakan bahwa politik adalah macam-macam kegiatan dalam suatu sistem politik negara yang menyangkut proses menentukan tujuan-tujuan dari sistem dan melaksanakan tujuan untuk mengambil keputusan mengenai apa yang menjadi tujuan dari sistem politik. Untuk melaksanakan tujuan perlu ditentukan kebijakan umum yang menyangkut pengaturan dan pembagian atau alokasi dari sumber yang ada. Untuk melakukan kebijaksaan itu perlu dimiliki kekuasaan dan wewenang yang dipakai baik untuk membina kerjasama atau pun untuk menyelesaikan konfik yang mungkin timbul dalam perselisihan (Budiardjo, 1983: 8).
Orang-orang Ternatememperlakukan rakyat Moro seperti budak, merampas hasilhasil pertanian dan perkebunan mereka. Mereka sering harus lari ke hutan karena rumah dan kampung halamannya diserang dan dibakar. Pada suatu hari, keadaan yang tidak menentramkan ini dituturkan Raja Moro Tioliza kepada Gonsalo Velozo, seorang pedagang portugis yang mengunjungi Mamuya. Pedagang Portugis itu menasehati Raja Moro agar beralih ke agama Kristen dan meminta perlindungan tentara Portugis.

Ketika Velozo kembali ke Ternate, Raja Moro mengirim beberapa orang untuk melaporkan situasi Moro kepada Gubernur Portugis dan menyampaikan keinginan mereka memeluk agama Kristen. Gubernur Tristao de Ataide menyambut hangat dan menerima permohonan mereka. Para utusan yang diterima di benteng Gamlamo itu kemudian dibaptis sebelum bertolak kembali ke Moro (Amal, 2010a : 214). Setiba kembali di Mamuya, para utusan itu melaporkan semua sambutan yang mereka peroleh di Ternate. Setelah menerima laporan, Raja Moro mengundang para bobato ${ }^{1}$-nya dan membahas laporan utusan mereka yang kini telah memeluk Kristen. Diputuskan bahwa Raja dan para bobato akan segera ke Ternate untuk dibaptis (Amal, 2010a: 215).

Sedikit penjelasan mengenai bobato ini, karena bobato dianggap sebagai pemimpin dari sebuah unit sosiopolitik yang berlaku dari setiap desa saat itu. Keterkaitan para bobato dengan daratan (atau bumi) ini dapat dengan jelas dipahami melalui upacara yang sering dilakukan di Tidore dimana barang-barang kebesaran disebut dengan bobato. Penjelasan ini sesuai dengan fenomena umum yang terjadi di semua kawasan Asia yang ditiup oleh angin musim di mana dewa bumi mewujud di antara para manusia di muka bumi di dalam sebuah objek yang menjadi bagian dari tanda kebesaran (regalia). Selama

1 Secara umum digunakan untuk menunjuk kepala persekutuan atau pelaksana peraturan 
upacara, pemimpin kelompok ini dikenali sebagai dewa dan menjadi perantara yang melaluinyalah kekuatan dewa mengalir deras guna memberikan jaminan kesuburan dan oleh karenanya [juga] kemakmuran dan kesejahteraan masyarakat (Andaya, 2015: 76-77).

Selang beberapa minggu kemudian, Raja Moro dan bobato berikut beberapa pengiring telah berada di dalam benteng Gamlamo serta diterima Gubernur Ataide dan para misionaris. Dalam suatu acara megah, Raja Moro yang mengenakan pakaian bangsawan Portugis pemberian Ataide dan memperoleh nama baptis Don Jao de Mamuya. Dengan pembaptisan ini, Raja Moro memperoleh ketenangan batin karena ibukota kerajaannya akan memperoleh bantuan untuk menangkal seranganserangan dari orang Ternate yang bermukim di Galela dan beragama Islam. Beralihnya Raja Moro ke dalam agama Kristen segera diikuti oleh rakyat di ibukotanya Mamuya dan terbentuklah komunitas Kristen pertama di kerajaan Moro di kota itu (Amal, 2010b: 216).

Kisah di atas menunjukkan bahwa hegemoni perebutan kekuasaan dapat berarti luas sehingga raja Moro mengambil keputusan untuk memeluk agama yang dibawa oleh bangsa Portugis yakni Kristen demi mendapat perlindungan dan bantuan untuk menangkal serangan orang Ternate yang bermukim di sekitar Galela. Sisi lainnya, Raja Moro melihat keadaan sosial budaya rakyatnya pasti mengalami perubahan dengan adanya tekanan terusmenerus dari Ternate untuk dapat memenuhi kebutuhan pangan.

Adapun untuk memenuhi keperluan dalam suatu kepentingan dengan pihak/ masyarakat lainnya, tentu akan dibutuhkan hubungan-hubungan dan kerjasama dengan orang lain dengan jalan mengorganisir bermacam-macam kelompok. Hal ini berdasarkan asumsi dasar bahwa batu lumpang memiliki hubungan yang tidak langsung terhadap sebuah hegemoni kekuasaan lokal dan kekuasaan Ternate dimana Kerajaan Moro harus mematuhi kebutuhan pangan yang akan dikirim.

Sebagai ilustrasi pendekatan, dapat diberikan contoh, masyarakat pedesaan yang berdiam di sepanjang tepi Danau Sentani Irian Jaya memperlihatkan suku yang relatif tertutup. Dalam pemilihan seorang pemimpin adat dipilih seorang yang berasal dari elit tradisional yang mempunyai kekuasaan setingkat lebih tinggi dibandingkan kelompok yang biasa. Kepanjangan tangan dari kondisi seperti ini bisa dilihat dalam hal pemanfaatan sumbersumber daya alam di sepanjang wilayah adat. Kelompok elit merasa mempunyai hak menguasai, sebaliknya kelompok biasa hanya hak pakai saja (Revassy, 1990: 110).

Pada suku pedesaan di tepi Danau Sentani untuk memperlihatkan kesetiaannya kepada pimpinannya, mereka ikut dalam pelaksanaan upacara ritual terkait dengan kematian seorang pimpinan. Selain itu juga bila seorang ingin menjadi pimpinan baru, terlebih dahulu harus melalui tiga dimensi yaitu dimensi ekonomi, dimensi religius, dan dimensi politik. Adapun pertama, dalam pelaksanaan dimensi ekonomi, calon pimpinan baru melakukan tukar barang kepada masyarakat elit tradisional dan kelompok biasa, kedua dimensi religius ikut dalam upacara-upacara ritual, dan ketiga dimensi politik ditunjukkan untuk calon pemimpin supaya mendapat perhatian dari suku tersebut, maka ikut dalam prosesi penguburan pimpinan yang meninggal. Apabila ketiga dimensi itu tidak dijalani maka calon pimpinan baru tidak dipilih oleh suku tersebut, karena dianggap mengabaikan tradisi leluhur yang sudah ada sejak lama (Revassy, 1990: 111).

Faktor kekuasaan (power) dan wewenang (authority) memberi kesan yang tegas sehingga batu lumpang memiliki nilai (value) untuk pemenuhan kebutuhan pangan yang tentu saja sangat pokok kala itu. Pada waktu tradisi megalitik berkembang dengan pesat yaitu di masa perundagian, diduga 
telah terbentuk masyarakat megalitik. Pada waktu itu penduduk sudah tinggal menetap di desa-desa kecil semacam perdukuhan atau perkampungan (village), hidup bertani dan mengembangbiakkan binatang, baik untuk keperluan hidup sehari-hari maupun untuk keperluan upacara-upacara tertentu. Pada tiap-tiap dukuh terdapat beberapa tempat tinggal yang dibangun secara tidak beraturan. Pola-pola perkampungan atau tempat tinggal di masa itu umumnya ditentukan oleh beberapa faktor fisik seperti topografi, iklim dan potensi pertanian (Soejono 1996: 196197).

Masyarakat yang hidup dalam lingkungan perdukuhan pada masa itu, bukan seperti kumpulan masyarakat yang heterogen seperti sekarang ini, tetapi merupakan kumpulan masyarakat yang homogen yang memiliki satu sistem kepercayaan serta umumnya hidup dalam kebersamaan. Dari kehidupan yang homogen dan sudah menetap di satu tempat tersebut, tentunya sangat mendukung untuk bertambah pesatnya pertumbuhan dan perkembangan penduduk. Pada masa tersebut diperkirakan perkembangan tatanan masyarakat dengan perbedaan status sosial atau pelapisan masyarakat sudah mulai ada. Berbagai faktor kepentingan yang mendasarinya sehingga kumpulan masyarakat yang berbeda baik dari kerajaan Moro dan kerajaan Ternate memberi gambaran struktur ekonomi pemenuhan kebutuhan pangan pada masa lalu. Sosial budaya juga berpengaruh karena penaklukan Ternate terhadap kerajaan Moro sudah menyentuh tatanan yang homogen dan sebelumnya bersifat lokalitas.

\section{KESIMPULAN}

Paparan di atas merupakan sebuah hasil observasi dan survei langsung di lapangan ketika penelitian tahun anggaran 2014. Berdasarkan uraian sebelumnya, dapat ditarik beberapa kesimpulan dari hasil penelitian yang dilakukan. Kesimpulan yang diperoleh adalah sebagai berikut:
Fungsi batu lumpang dahulu digunakan untuk pemenuhan kebutuhan makanan. Batu lumpang merupakan sebuah teknologi pengupas kulit padi atau alat/ perkakas penumbuk umbi pada masa itu dan masih digunakan sampai masa kerajaan Moro hingga beberapa periode sesudahnya. Batu lumpang merupakan tinggalan dari masa bercocok tanam yang masih digunakan hingga masa dimana berkembang pesat sebuah kerajaan Moro yang bersifat lokalitas di Halmahera Utara. Faktor hegemoni kekuasaan dari kerajaan Ternate yang menaklukkan kerajaan Moro, memberikan sebuah perjanjian agar kerajaan Moro memenuhi juga kebutuhan pangan di Ternate karena berlimpahnya sumber bahan pangan di Moro merupakan sebuah faktor yang menjadikan indikasi kuat batu lumpang sebagai penyokong aktivitas ekonomi pada masa lampau.

Pada bagian saran dalam penulisan ini dikarenakan penelitian ini masih bersifat studi awal dan masih sangat eksploratif, maka banyak hal yang bisa dikembangkan untuk penelitian masa mendatang. Tinggalan batu lumpang di desa Ruko yang sangat minim harus bisa dijaga oleh masyarakat, karena cuplikan data tersebut (batu lumpang) bisa menceritakan proses dan perkembangan budaya pada masa lampau. Satu hal mendasar juga yaitu kebudayaan lokal menjadi unsur konstitutif kebudayaan nasional, demikian ungkapan para ahli. Memperkaya kebudayaan lokal berarti memperkaya kebudayaan nasional.

\section{Ucapan Terima Kasih}

Pada bagian ini saya menyempatkan mengucapkan terima kasih kepada Wuri Handoko, S.S sebagai Ketua Tim Penelitian di Halmahera Utara 2014. Penelitian yang bertajuk "Jejak Peradaban Islam dan Pengaruh Kesultanan Ternate di Pulau Halmahera" merupakan sebuah penelitian eksploratif dan dikembangkan di lapangan untuk melihat sejauh mana sistem kesultanan dahulu mempengaruhi berbagai sisi 
kehidupan masyarakatnya. Adapun anggota penelitian yang turut serta dalam Tim Halmahera Utara 2014 adalah, Dominggas Pentury, Andrew Huwae, Fiona Latupapua, dan Martin Paliama yang kesemuanya juga saya tidak lupa mengucapkan terima kasih atas kerjasamanya di lapangan.

\section{$* * * * *$}

\section{DAFTAR PUSTAKA}

Amal, M. Adnan. (2010)a. Kepulauan RempahRempah; Perjalanan Sejarah Maluku Utara 1250-1950. Jakarta: Kepustakaan Populer Gramedia.

Amal, M. Adnan. (2010)b. Portugis dan Spanyol di Maluku. Jakarta: Komunitas Bambu.

Amal, M. Adnan. (2013). Tobelo Tempo Doeloe Deskripsi Tentang Alam Pikiran, Kebudayaan dan Kesenian. Tobelo: Dinas Pariwisata dan Kebudayaan Kabupaten Halmahera Utara.

Andaya, Leonard Y, (2015). Dunia Maluku Indonesia Timur Pada Zaman Modern Awal. Yogyakarta: Penerbit Ombak.

Binford, Lewis R. (1972). An Archaeological Prespective. New York, San Fransisco: London Seminar Press.

Budiardjo, Mariam. (1983). Dasar-Dasar Ilmu Politik. Jakarta: PT Gramedia.

Endraswara, Suwardi. (2006). Metode, Teori, Teknik Penelitian Kebudayaan. Sleman: Pustaka Widyatama.

Herkovits, Mcville J, (1952). Anthropology and Economics. The Economic Life of Primitive Peoples. New York: Knopf.

Naping, Hamka, dkk. (2013). Halmahera Utara Sejarah Perkembangan Peradaban di Bumi Hibualamo. Makassar : Yayasan Bina Generasi.

Revassy, Lazarus. (1990). Perspektif Kepemimpinan di Pedesaan Irian Jaya (antara mitos dan realistis). Jurnal Ilmu Politik No.7. Jakarta: PT. Gramedia.

Simanjuntak, T. et al. (1999). Metode Penelitian Arkeologi. Jakarta: Puslit Arkenas.
Soejono, R.P. (1996). Jaman Prasejarah di Indonesia. Sejarah Nasional Indonesia I. Jakarta: Departemen Pendidikan dan Kebudayaan. Balai Pustaka.

Tim Penelitian, 2014. Jejak Peradaban Islam dan Pengaruh Kesultanan Ternate di Pulau Halmahera. Laporan Penelitian. Ambon: Balai Arkeologi Ambon. 